\title{
OPEN Effect of sowing proportion on above- and below-ground competition in maize-soybean intercrops
}

\author{
Yuanyuan Ren ${ }^{1,2}$, Li Zhang ${ }^{2}$, Minfei Yan ${ }^{3}$, Yanjun Zhang ${ }^{1}$, Yinglong Chen ${ }^{3,4}$, Jairo A. Palta ${ }^{4,5}$ \& \\ Suiqi Zhang ${ }^{3 \bowtie}$
}

The relative contribution of above- and below-ground competition to crop yield under intercropping systems is critical to understanding the mechanisms of improved yield. Changes in the content of above- and below-ground biomass, leaf photosynthetic rate ( $\mathrm{Pn})$, leaf area index (LAl), chlorophyll meter reading (SPAD), diffuse non interceptance (DIFN), soil water storage (SWS), crop nitrogen (N), and phosphorus $(P)$ uptake were examined in a 2-year trial of different maize-soybean intercropping systems on the Loess Plateau, China. Compared with the sole cropping system, shoot biomass of maize was increased by $54 \%$ in M2S2 and 62\% in M2S4 strip intercropping treatment. The crop N and P uptake of maize increased significantly, by $54 \%$ and $50 \%$ in M2S2 and by $63 \%$ and $52 \%$ in M2S4 compared with their respective sole crop. LAl values of maize in intercropping systems were $14 \%$ and $15 \%$ for M2S2 and M2S4 less than that in the sole crop. The DIFN of intercropped maize was increased by $41 \%$ and $48 \%$ for M2S2 and M2S4 compared to monocrop. There were no significant differences in $\mathrm{Pn}$ and SWS in both crops between the two cropping systems. The contribution rate of DIFN in M2S2 and crop P uptake in M2S4 on the biological yield in intercropping system was the highest among all factors. We conclude that the sowing proportion affects above- and below-ground competition in maize-soybean intercropping systems.

The key to ensuring food security in more densely populated countries, such as China, is to improve crop yield on the existing cultivated land ${ }^{1,2}$. Modern agricultural production (sole crop) mode is characterized by a single form, and the pursuit of high input and high yield is known to lead to many ecological and environmental problems $\mathrm{s}^{3,4}$. Intercropping systems, especially cereal-legume intercropping systems, have been proven to play a vital role in mitigating these problems. Intercropping cereal crops with legumes can increase the soil nitrogen availability through atmospheric nitrogen fixation, thereby reducing the dependence on nitrogen fertilizer and the risk of nitrogen losses through leaching 5 . The advantages of intercropping include increasing light, water, nutrients use efficiency, and reduction in competition from weeds and pressure from herbivores and pathogens ${ }^{6}$. Intercropping can also improve land-use efficiency ${ }^{7}$ and increase diversity in an agroecosystem, which is vital for stabilization of ecosystem productivity, especially when the climate is undergoing rapid changes ${ }^{8}$.

Interspecific interactions, including both above- and below-ground relationships, play prominent parts in determining the structure and dynamics of crop populations in agroecosystems $s^{9,10}$. Previous studies on the effect of above-ground interactions on the yield have been reported ${ }^{7,11}$. Interactions between species include interspecific facilitation and interspecific competition ${ }^{12}$. Competition for sunlight is perhaps one of the most important interspecific above-ground interactions in intercropping ecosystems ${ }^{13}$. The parameters related to sunlight use include leaf area index (LAI $)^{14}$, chlorophyll meter reading (SPAD $)^{15}$, diffuse non interceptance (DIFN) and leaf photosynthesis rate $(\mathrm{Pn})^{16}$. In an intercropping system, taller crops seek more light and suffer slight competition when sharing light with companion crops $^{14}$; also, for shorter crops, plant height increases and leaf photosynthesis

${ }^{1}$ Geography and Environmental Engineering Department, Baoji University of Arts and Sciences, Baoji 721013, China. ${ }^{2}$ State Key Laboratory of Soil Erosion and Dryland Farming on the Loess Plateau, Institute of Soil and Water Conservation, Chinese Academy of Sciences and Ministry of Water Resources, Yangling 712100, Shaanxi, China. ${ }^{3}$ State Key Laboratory of Soil Erosion and Dryland Farming on the Loess Plateau, Northwest A\&F University, Yangling 712100, Shaanxi, China. ${ }^{4}$ School of Plant Biology, The University of Western Australia, Perth, WA 6009, Australia. ${ }^{5}$ CSIRO Agriculture and Food, Private Bag No. 5, Wembley, WA 6913, Australia. ${ }^{\square}$ email: sqzhang@ ms.iswc.ac.cn 
rate decreases due to shading from taller crops ${ }^{17}$. The belowground competition for resources such as nutrients and water are also critical in improving crop yield under intercrops. Below-ground interspecies interactions contributed to the increased yields due to water movement in maize-pea intercropping systems ${ }^{18}$ and nutrient uptake in maize-soybean intercropping systems ${ }^{16}$ as a result of root growth ${ }^{19,20}$.

Such prior studies found that there were strong interactions between root and shoot competition ${ }^{21}$, belowground competition usually affected the balance between the competing species more than above-ground competition $^{16,22}$, and the contribution of above-ground interactions to crop growth was higher than that of below-ground interaction ${ }^{13}$. Previous research mainly evaluated the effects of above- and below-ground competition on the growth of intercropping system through separation treatments, such as no separation, above-ground separation, below-ground separation, above- and below-ground separation ${ }^{23,24}$. These studies typically consisted of separation experiments of shoots and roots under controlled environments ${ }^{14,25,26}$ or field conditions ${ }^{13,16,27}$ that possibly cause damage to the original structure of the soil layer, which can influence quantification of the relative contribution of the above- and below-ground competition to the yield of intercrops. In addition, previous studies only qualitatively reported the effects of above- and below-ground competition on the growth intercropping systems, without quantifying the influence of above- and below-ground competition to the growth of intercropping systems. Therefore, the contribution of the above- and below-ground competition to growth of intercropping systems in the field remains unclear. To resolve this question, we collected observations on the interaction between above- and below-ground of intercropped crops under different cropping systems in the field to quantify the sources of intercropping advantages. The objectives of this study were to (1) compare yield, above- and below-ground related parameters (Pn, LAI, SPAD, DIFN, soil water storage, nitrogen and phosphorus uptake) in different maize-soybean intercrops, and (2) quantify the relative contributions of above- and belowground competition to intercrop system performance.

\section{Results}

Crop biomass, LER and WER. Compared with the sole cropping system, the shoot biomass of the intercropped maize increased 54\% and 62\% for M2S2 and M2S4, respectively (Fig. 1a) whereas shoot biomass of intercropped soybean was no change or decrease (Fig. 1b). The root biomass of intercropped maize under M2S4 increased $38-178 \%$ compared with sole crop (Fig. 1c). The root biomass of soybean under M2S4 was no difference compared with sole-cropped soybean (Fig. 1d). Compared with the sole cropping systems, the land equivalent ratio (LER) based on the yield in intercropping systems increased 18\% and 19\% for M2S2 and M2S4, respectively (Fig. 2a), suggesting that maize-soybean intercropping systems have intercropping advantage in land-use efficiency. The water equivalent ratio (WER) in intercropping systems increased by $25 \%$ and $6 \%$ in M2S2 and M2S4, respectively, compared to monocrops (Fig. 2b), showing that intercropping can improve water use efficiency in maize-soybean intercrop.

Above-ground interaction. There were no differences for the Pn of crops (maize and soybean) under sole cropping and intercropping systems in both years (Table 1). There were substantial variations among different cropping systems in the LAI values for maize and soybean in both years. The LAI of intercropped maize was reduced $14 \%$ and 15\% for M2S2 and M2S4 compared to sole crop (Fig. 3a), and similarly, the LAI of intercropped soybean was reduced $25 \%$ and $23 \%$ for M2S2 and M2S4 compared to sole crop (Fig. 3b). The SPAD of intercropped maize was increased $4 \%$ and $5 \%$ for M2S2 and M2S4 compared to monocrop, and there was no difference for SPAD of soybean among different cropping systems (Fig. 3c, d). The DIFN of intercropped maize was increased $41 \%$ and $48 \%$ for M2S2 and M2S4 compared to monocrop, and DIFN of intercropped soybean was 4.82 and 3.30 times for M2S2 and M2S4 compared to monocrop (Fig. 3e, f).

Below-ground interaction. There was no difference in soil water storage (SWS) or evapotranspiration (ET) between intercropping and monocropping (Fig. 4). There was no difference for $\mathrm{N}$ concentration of maize, and for P concentration of maize between monocrop and intercrops except M2S4 in 2013 (Table 2). There was no difference in $\mathrm{N}$ and $\mathrm{P}$ concentration of soybean among different cropping systems (Table 2). The nitrogen (N) uptake of maize increased significantly (54\% in M2S2 and 63\% in M2S4) under intercrops compared to sole crop. The N uptake of soybean in intercrop decreased (22\% in M2S2 and 35\% in M2S4) compared to monocrop (Table 2). The variables of phosphorus (P) of maize coincided with the degree of nitrogen of maize. The $\mathrm{P}$ uptake of maize increased significantly (50\% in M2S2 and 52\% in M2S4) under intercrops compared to the sole crop. The P uptake of soybean in intercrop decreased $25.2 \%$ and $25.4 \%$ for M2S2 and M2S4 compared to monocrop. There were significant nutrient uptake advantages when maize intercropped with soybean compared to monocrop, showing that below-ground competition between intercropped crops plays an important role in the process of crop growth.

Contribution to biological yield. There was a correlation between LER and maize above-ground biomass $(R=0.589, P<0.05)$ and soybean above-ground biomass $(R=0.672, P<0.01)$, respectively (Table 3$)$. The biomass of maize increased while that of soybean decreased in intercrops, which indicated that the advantage of intercropping in yield was mainly due to the increase of maize yield. In addition, there was no difference in ET between monocrop and intercrop, which improved the water use efficiency of intercropping system. In order to quantify the contribution of above- and below-ground interactions to biological yield, a relationship was obtained between biological yield and impact factors by linear regression. The biological yield (Y) is closely correlated with LAI, SPAD, DIFN, SWS, and the crop N and P uptake (Sole crop: Y $=-1.67 \mathrm{LAI}-0.50 \mathrm{SPAD}+$ 119DIFN - 0.01SWS + 0.008 N-1.10P + 7.22 $\times 10^{-7} \mathrm{X}+64, R^{2}=0.96, P<0.05 ; \mathrm{M} 2 \mathrm{~S} 2: \mathrm{Y}=0.62 \mathrm{LAI}-0.44 \mathrm{SPAD}+1$ 89DIFN +0.01SWS $-0.004 \mathrm{~N}-0.08 \mathrm{P}+1.09 \times 10^{-7} \mathrm{X}+15.32, R^{2}=0.99, P<0.01 ; \mathrm{M} 2 \mathrm{~S} 4$ : Y $=0.08 \mathrm{LAI}-0.05 \mathrm{SPAD}$ 

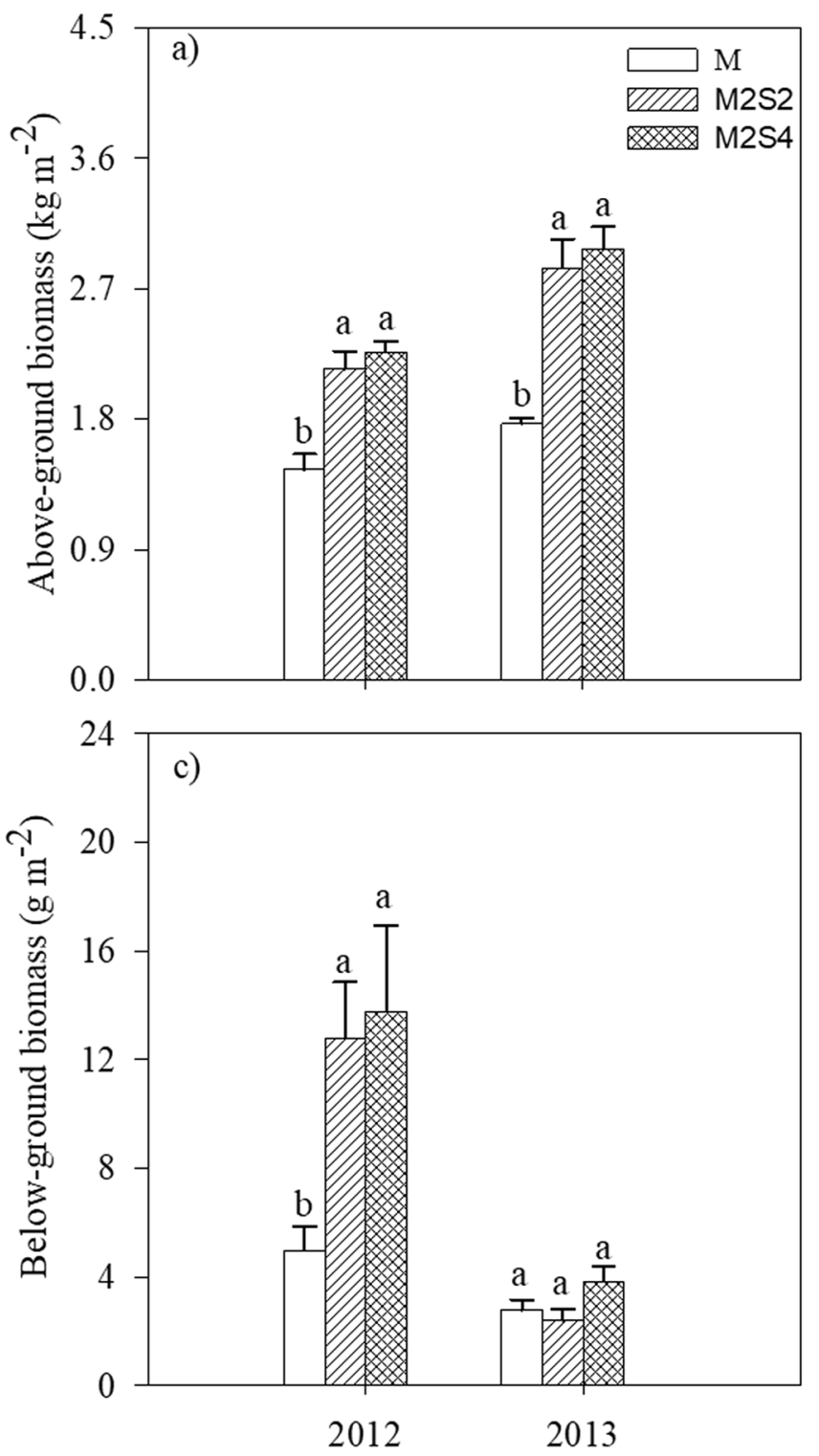
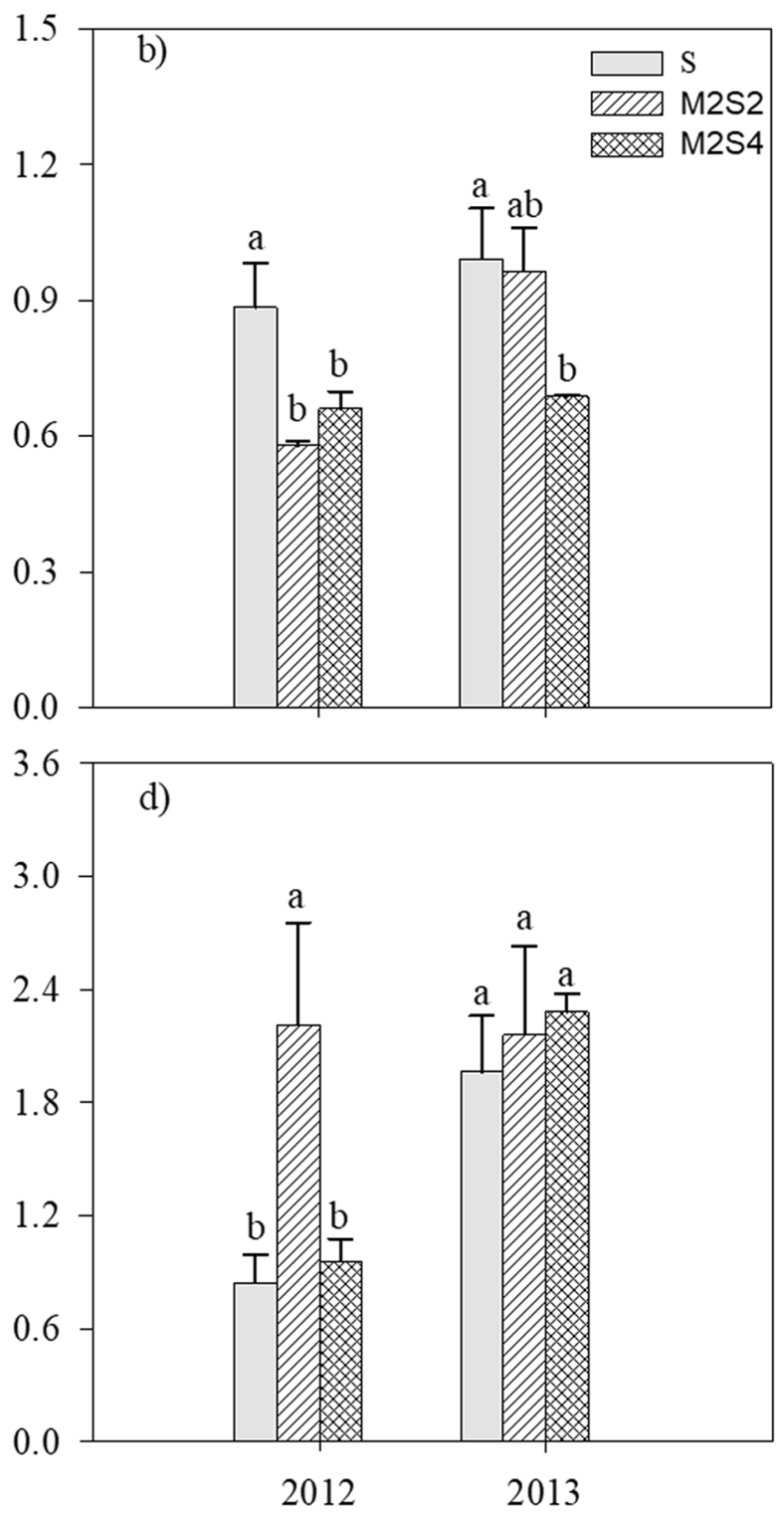

Figure 1. Above- and below-ground biomass of maize (a, c) and soybean $(\mathbf{b}, \mathbf{d})$ grown under sole cropping and intercropping systems in 2012 and 2013. Bars are means + standard errors. Bars with different letters are significantly different between cropping systems for each year $(P<0.05)$. M, sole-cropped maize; $\mathrm{S}$, solecropped soybean; M2S2, two rows of maize intercropped with two rows of soybean; M2S4, two rows of maize intercropped with four rows of soybean.

$+56 \mathrm{DIFN}+0.04$ SWS $\left.-0.03 \mathrm{~N}+1.10 \mathrm{P}-8.11 \times 10^{-8} \mathrm{X}-34.14, R^{2}=0.99, P<0.01\right)$. The yield in the sole cropping system was mainly determined by DIFN, as the contribution value of DIFN $(|-1.20|)$, and the second factor by crop P uptake (|-0.97|) (Fig. 5), indicating that there were both above- and below-ground competitions. The yield in the intercropping system M2S2 was mainly determined by DIFN $(|0.96|)$, mainly from the aboveground competition. The yield in the intercropping system M2S4 was mainly determined by the crop P uptake, as the contribution value of crop P uptake (|0.88|) was larger than that of other impact factors (Fig. 5), primary results from below-ground competition. Results clearly indicate that different planting patterns affect the above- and below-ground competition.

\section{Discussion}

The maize-soybean intercropping enhanced land use efficiency $18 \%$ in M2S2 and 19\% in M2S4, as indicated by LER (Fig. 2), showing that there was a greater biological efficiency in the maize-soybean intercropping system. There was a correlation between LER and above-ground biomass of maize and soybean, respectively (Table 3), indicating that yield was significantly positively correlated with the above-ground growth ${ }^{28,29}$. In addition, we found that maize yield had a significant positive correlation with the $\mathrm{P}$ uptake $(R=0.685, P<0.05)$. The advantages of intercropping therefore appear to be related primarily to cereal, which is the dominant species with higher competitiveness compared with legumes in the cereal-legume intercrop ${ }^{30}$. 

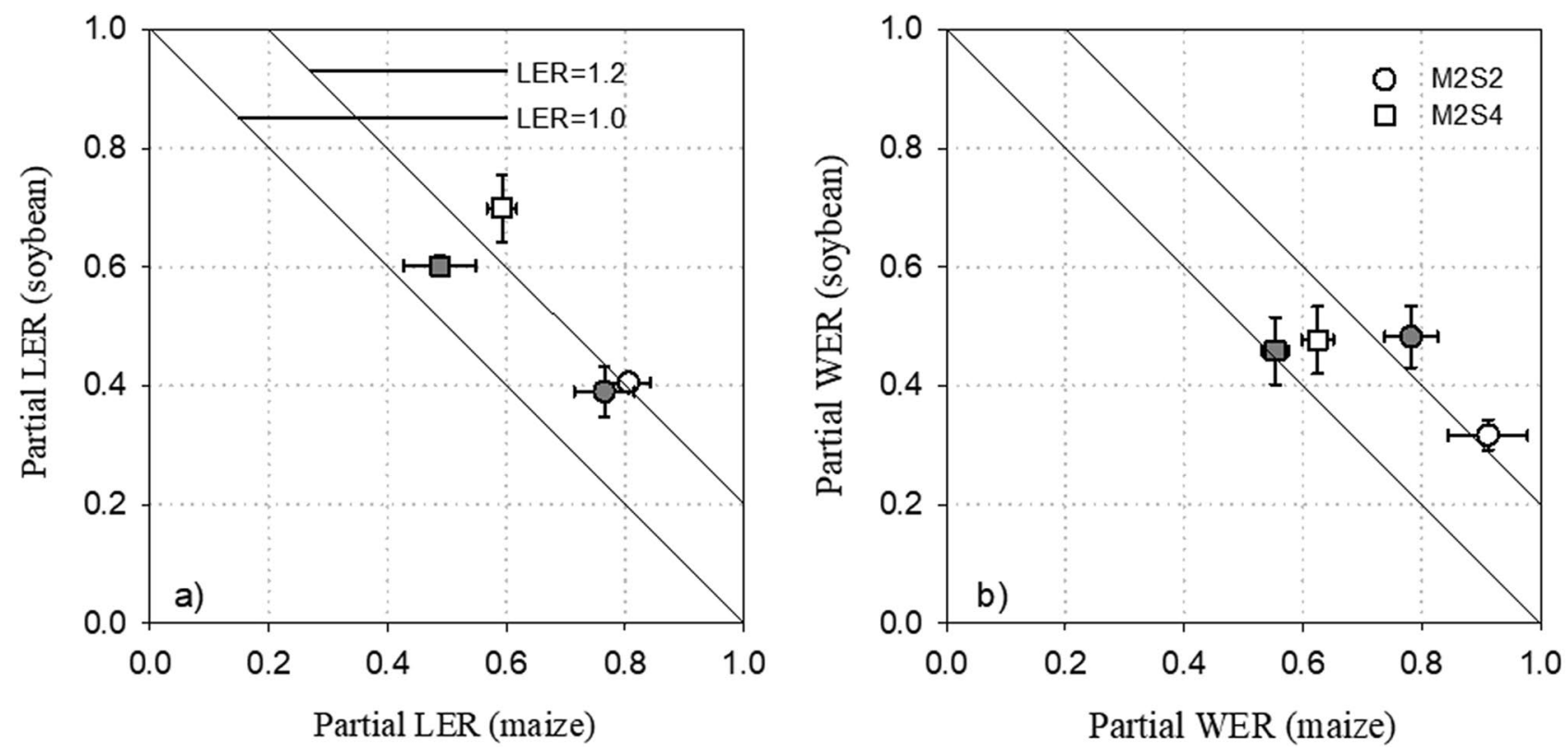

Figure 2. Partial land equivalent ratio (partial LER, a) and water equivalent ratio (partial WER, b) of the maize and soybean under intercrop systems in 2012 (white symbols) and 2013 (gray symbols) on the basis of yield. Bars are means \pm standard errors.

\begin{tabular}{|c|c|c|c|c|}
\hline \multirow[b]{2}{*}{ Cropping system } & \multicolumn{2}{|c|}{ Pn of maize } & \multicolumn{2}{|c|}{ Pn of soybean } \\
\hline & 2012 & 2013 & 2012 & 2013 \\
\hline Sole crop & $13.58 \mathrm{a}$ & $18.50 \mathrm{a}$ & $10.08 \mathrm{a}$ & $7.21 \mathrm{a}$ \\
\hline $\mathrm{M} 2 \mathrm{~S} 2$ & $17.44 \mathrm{a}$ & $17.85 \mathrm{a}$ & $9.06 \mathrm{a}$ & $5.85 \mathrm{a}$ \\
\hline $\mathrm{M} 2 \mathrm{~S} 4$ & $15.20 \mathrm{a}$ & $21.05 \mathrm{a}$ & $9.32 \mathrm{a}$ & $6.04 \mathrm{a}$ \\
\hline \multicolumn{5}{|l|}{ ANOVA } \\
\hline Year & \multicolumn{2}{|l|}{$* *$} & \multicolumn{2}{|l|}{$* * * *$} \\
\hline Cropping system & \multicolumn{2}{|l|}{ ns } & \multicolumn{2}{|l|}{ * } \\
\hline Year $\times$ cropping system & \multicolumn{2}{|l|}{ ns } & \multicolumn{2}{|l|}{ ns } \\
\hline
\end{tabular}

Table 1. The leaf photosynthetic rate $\left(\mathrm{Pn}, \mu \mathrm{mol} \mathrm{m} \mathrm{m}^{-2}\right)$ of maize and soybean under sole cropping and intercropping systems in 2012 and 2013. M2S2-two rows of maize intercropped with two rows of soybean; M2S4-two rows of maize intercropped with four rows of soybean. ${ }^{*}$, significant at 0.05 level; ${ }^{* *}$, significant at 0.01 level; ${ }^{* *}$, significant at 0.001 level; ns, no significant difference. For each column, mean values indicated by different letters are significantly different at the $5 \%$ level using LSD.

Above-and below-ground interaction. The advantage of intercropping is due to above- and belowground interactions. This study showed no difference in the photosynthetic rate of both soybean and maize between intercropping and sole cropping systems. Similar results were found for soybean intercropped with maize $^{4}$ or wheat ${ }^{31}$. LAI has been shown to be an effective method by which to evaluate light absorption, and the photosynthetic rate of a crop is directly affected by the LAI ${ }^{29,32}$. We found that the LAI of intercropped soybean and maize are lower than that of the corresponding sole crop, indicating that the two species restrained each other in LAI of the competing crop when intercropped ${ }^{33}$. The DIFN was significantly improved under intercrops, showing that intercrop increased light transmission of the canopy and decreased the waste of light energy $^{34}$. The maize-soybean intercrop improved the $\mathrm{N}$ and $\mathrm{P}$ uptake in maize, and there was no change for $\mathrm{N}$ and $\mathrm{P}$ concentration in maize, showing that $\mathrm{N}$ and $\mathrm{P}$ uptake improved were the consequence of increased in biomass production. This is consistent with the results of previous research on maize intercropping with faba bean $^{20}$, soybean ${ }^{16}$, and cowpea ${ }^{35}$. Nitrogen leached from the root zone of soybean could be absorbed by nearby roots of maize, indicating that intercropping improve nitrogen fertilization absorption ${ }^{36}$. The maize-soybean intercrops promoted nitrogen fixation of soybean from air, and nitrogen could transfer from soybean to maize in intercrops, which would be beneficial to improve nitrogen fertilization absorption of maize. The soybean could have the ability to acidify the rhizosphere by releasing protons and mobilizing insoluble soil phosphorus by exuding malate and citrate, which could increase phosphorus fertilization absorption of maize. 

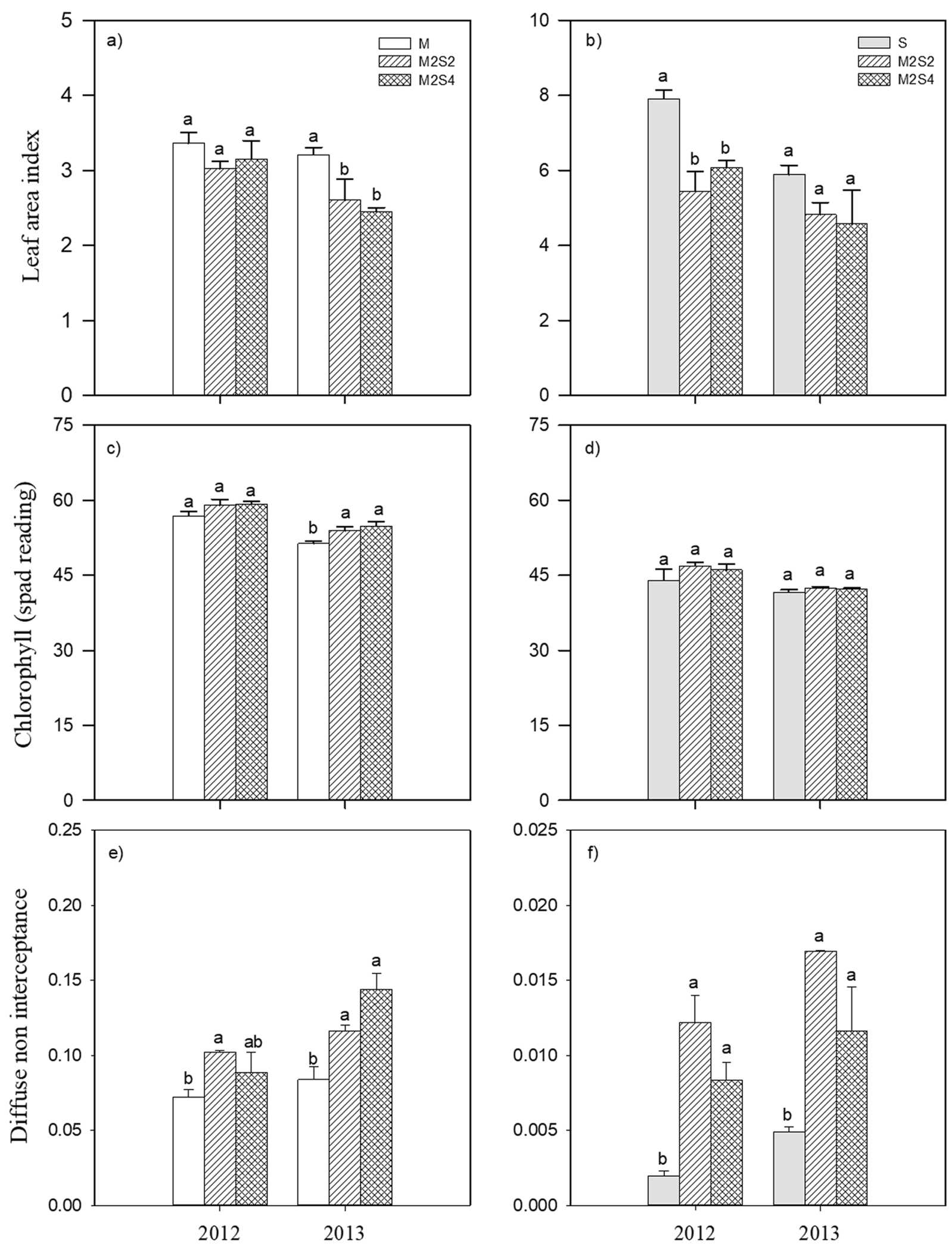

Figure 3. Leaf area index, chlorophyll (spad reading), diffuse non interceptance of maize (a, c, e) and soybean (b, d, f) grown under sole crop and intercrop systems in 2012 and 2013. Bars are means + standard errors. Bars with different letters are significantly different between cropping systems for each year $(P<0.05)$. M, solecropped maize; S, sole-cropped soybean; M2S2, two rows of maize intercropped with two rows of soybean; M2S4, two rows of maize intercropped with four rows of soybean. 


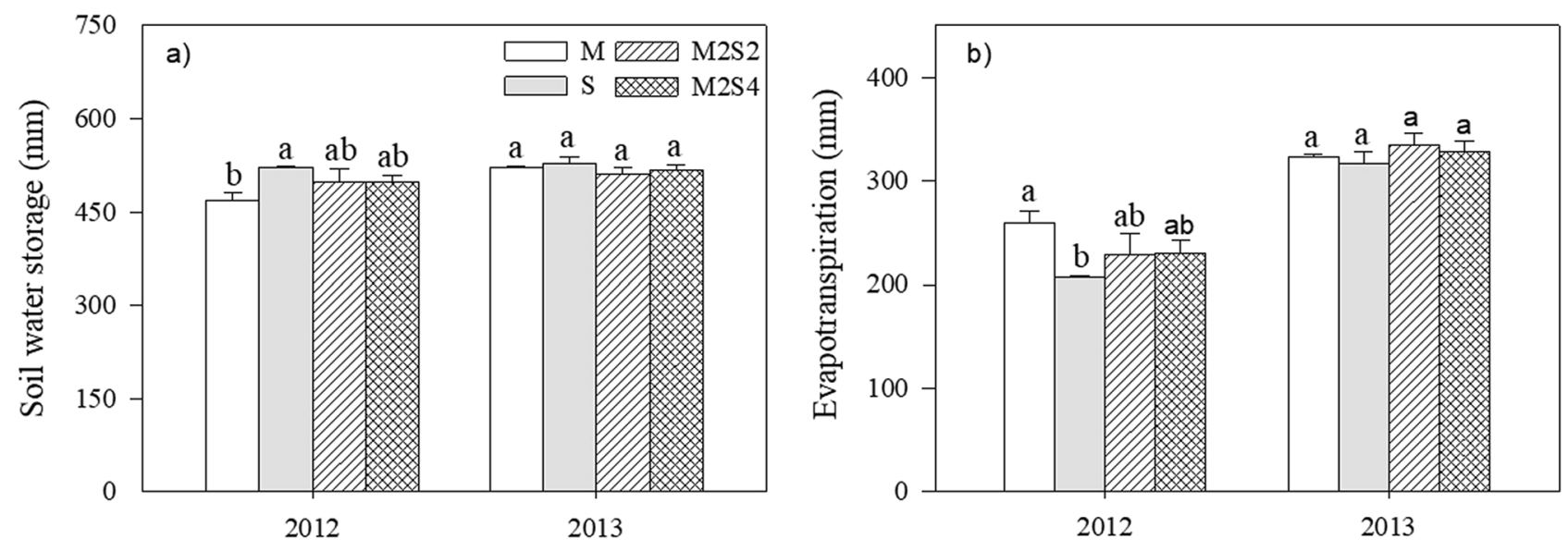

Figure 4. Soil water storage (a) and evapotranspiration (b) under sole cropping and intercropping systems. Bars are means + standard errors. Bars with different letters are significantly different between cropping systems for each year $(P<0.05)$. M, sole-cropped maize; $\mathrm{S}$, sole-cropped soybean; M2S2, two rows of maize intercropped with two rows of soybean; M2S4, two rows of maize intercropped with four rows of soybean.

\begin{tabular}{|c|c|c|c|c|c|c|c|c|}
\hline \multirow[b]{2}{*}{ Cropping system } & \multicolumn{2}{|c|}{$\begin{array}{l}\mathrm{N} \\
\text { concentration } \\
\text { (\%) }\end{array}$} & \multicolumn{2}{|c|}{$\begin{array}{l}\mathrm{N} \text { uptake }(\mathrm{kg} \\
\left.\mathrm{ha}^{-1}\right)\end{array}$} & \multicolumn{2}{|c|}{$\begin{array}{l}\text { P concentration } \\
(\%)\end{array}$} & \multicolumn{2}{|c|}{$\begin{array}{l}\text { P uptake (kg } \\
\left.\text { ha }^{-1}\right)\end{array}$} \\
\hline & 2012 & 2013 & 2012 & 2013 & 2012 & 2013 & 2012 & 2013 \\
\hline \multicolumn{9}{|l|}{ Maize } \\
\hline Sole crop & $1.38 \mathrm{a}$ & $1.16 \mathrm{a}$ & $200 \mathrm{~b}$ & $205 \mathrm{~b}$ & $0.11 \mathrm{a}$ & $0.13 a$ & $15.8 \mathrm{~b}$ & $22.7 \mathrm{~b}$ \\
\hline M2S2 & $1.35 \mathrm{a}$ & $1.18 \mathrm{a}$ & $289 \mathrm{a}$ & $337 \mathrm{a}$ & $0.11 \mathrm{a}$ & $0.12 \mathrm{ab}$ & $23.2 \mathrm{a}$ & $34.6 \mathrm{a}$ \\
\hline M2S4 & $1.41 \mathrm{a}$ & $1.15 \mathrm{a}$ & $319 a$ & $343 a$ & $0.12 \mathrm{a}$ & $0.10 \mathrm{~b}$ & $26.5 \mathrm{a}$ & $31.0 \mathrm{a}$ \\
\hline \multicolumn{9}{|l|}{ Soybean } \\
\hline Sole crop & $3.78 \mathrm{a}$ & $3.17 \mathrm{a}$ & $333 a$ & $294 \mathrm{a}$ & $0.19 \mathrm{a}$ & $0.21 \mathrm{a}$ & $16.2 \mathrm{a}$ & $19.7 \mathrm{a}$ \\
\hline M2S2 & $3.41 \mathrm{a}$ & $3.02 \mathrm{a}$ & $197 \mathrm{~b}$ & $286 a$ & $0.16 \mathrm{a}$ & $0.20 \mathrm{a}$ & $9.01 \mathrm{c}$ & $18.5 \mathrm{a}$ \\
\hline M2S4 & $3.38 \mathrm{a}$ & $2.70 \mathrm{a}$ & $222 \mathrm{~b}$ & $186 \mathrm{~b}$ & $0.20 \mathrm{a}$ & $0.19 \mathrm{a}$ & $13.3 \mathrm{~b}$ & $13.2 \mathrm{~b}$ \\
\hline \multicolumn{9}{|l|}{ ANOVA } \\
\hline Year & \multicolumn{2}{|l|}{ ** } & \multicolumn{2}{|l|}{ ns } & \multicolumn{2}{|l|}{ ns } & \multicolumn{2}{|l|}{$* * *$} \\
\hline Crop species & \multicolumn{2}{|l|}{$* * *$} & \multicolumn{2}{|l|}{ ns } & \multicolumn{2}{|l|}{$* * *$} & \multicolumn{2}{|l|}{$* * *$} \\
\hline Cropping system & \multicolumn{2}{|l|}{ ns } & \multicolumn{2}{|l|}{ ns } & \multicolumn{2}{|l|}{ ns } & \multicolumn{2}{|l|}{ ns } \\
\hline Year $\times$ crop species & \multicolumn{2}{|l|}{$\mathrm{ns}$} & \multicolumn{2}{|l|}{ ns } & \multicolumn{2}{|l|}{ ns } & \multicolumn{2}{|l|}{ ns } \\
\hline Year $\times$ crop system & \multicolumn{2}{|l|}{ ns } & \multicolumn{2}{|l|}{ ns } & \multicolumn{2}{|l|}{ ns } & \multicolumn{2}{|l|}{ ns } \\
\hline Crop species $\times$ crop system & \multicolumn{2}{|l|}{ ns } & \multicolumn{2}{|l|}{$* * *$} & \multicolumn{2}{|l|}{ ns } & \multicolumn{2}{|l|}{$* * *$} \\
\hline Year $\times$ crop species $\times$ crop system & \multicolumn{2}{|l|}{ ns } & \multicolumn{2}{|l|}{ ns } & \multicolumn{2}{|l|}{ ns } & \multicolumn{2}{|l|}{ ns } \\
\hline
\end{tabular}

Table 2. $\mathrm{N}$ and $\mathrm{P}$ concentration and uptake of maize and soybean grown under sole cropping and intercropping systems in 2012 and 2013. M2S2 - two rows of maize intercropped with two rows of soybean; M2S4-two rows of maize intercropped with four rows of soybean. ${ }^{*}$, significant at 0.05 level; ${ }^{* *}$, significant at 0.01 level; ${ }^{* * *}$, significant at 0.001 level; ns, no significant difference. The mean values indicated by a different letter in the same column are significantly different at the $5 \%$ level using LSD.

\begin{tabular}{|l|l|l|l|l|c|}
\hline & LER & Shootm & Shoots & Rootm & Roots \\
\hline LER & 1.00 & $0.59^{*}$ & $0.67^{* *}$ & 0.03 & -0.24 \\
\hline Shootm & $0.59^{*}$ & 1.00 & 0.34 & -0.29 & 0.05 \\
\hline Shoots & $0.67^{* *}$ & 0.34 & 1.00 & -0.33 & -0.10 \\
\hline Rootm & 0.03 & -0.29 & -0.33 & 1.00 & -0.41 \\
\hline Roots & -0.24 & 0.05 & -0.10 & -0.41 & 1.00 \\
\hline
\end{tabular}

Table 3. The correlation between LER and above- and below-ground biomass. ${ }^{\star}$, significant at 0.05 level; ${ }^{* *}$, significant at 0.01 level. Shootm and Shoots represent the above-ground biomass of maize and soybean, respectively. Rootm and Roots represent the below-ground biomass of maize and soybean, respectively. 


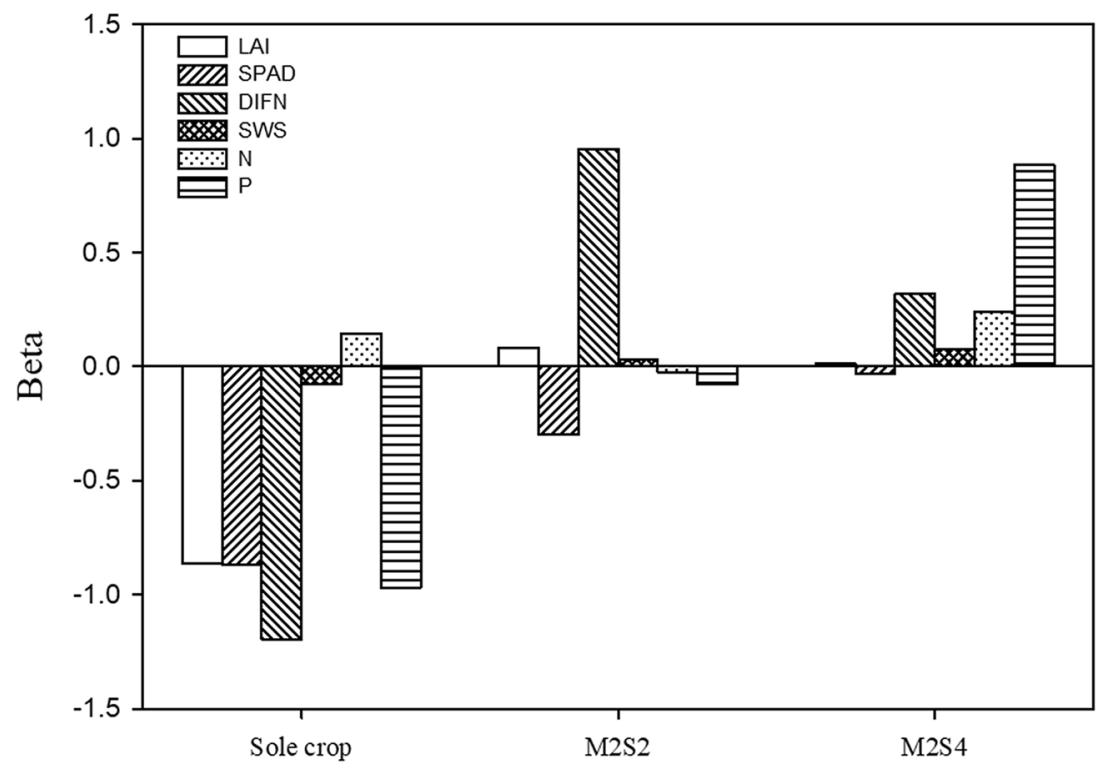

Figure 5. Contribution value of above- and below-ground interaction on the biological yield. M2S2, two rows of maize intercropped with two rows of soybean; M2S4, two rows of maize intercropped with four rows of soybean.

Contribution to biological yield. Some studies implied that below-ground competition have contributed greatly to intercrop advantages than above-ground interaction by shoot or root separation experiment in maizesoybean intercrops ${ }^{16}$. Some studies showed that intercrop advantages result from above-ground competition than below-ground competition by row spacing and root separation experiments in maize-soybean intercrops ${ }^{13}$. All of the previous studies on the impact of above- or below-ground interactions to intercropping advantage were studied by qualitative description. In our study, we quantified the effects of above- (Pn, SPAD, DIFN, and LAI) and below-ground (SWS, crop $\mathrm{N}$ and $\mathrm{P}$ uptake) interactions on intercropping systems by calculating the contribution rate.

The narrow-wide row configuration affect microclimate environment of interspecies, crop growth and yields because of different space and time for crop production ${ }^{37}$. We found that the above- and below-ground factors contribute to yield advantage in the order of DIFN $>$ SPAD $>$ LAI $>$ P $>$ SWS $>N$ in 2:2 planting pattern, and $\mathrm{P}>\mathrm{DIFN}>\mathrm{N}>\mathrm{SWS}>\mathrm{SPAD}>\mathrm{LAI}$ in 2:4 planting pattern. This shown that different intercrop pattern has an impact on crop yields on account of the above- and below-ground competition among intercropping systems ${ }^{13}$. For above-ground interaction, the row planting patterns affect the light transmission rate of intercropping species ${ }^{38}$, because close planting between different crops always causes mutual shading, especially for the shading of tall crops over short crops in intercropping systems, and then inevitably affect crop radiation interception $^{39}$, light interception ${ }^{40}$, and photosynthetically active radiation transmittances ${ }^{13}$. This result is consistent with the previous studies that intercropping patterns affects light use efficiency and light interception by regulating intraspecific and interspecific competition and compensating interactions ${ }^{40}$. We found the most important factor contributes to yield under M2S2 is above-ground competition for light, as contribution value of DIFN. Previous studies also found that above-ground interactions have more contributions to intercrop advantage than below-ground interactions in different intercropping systems ${ }^{13}$. Compared to M2S4 intercrop, above-ground interactions under M2S2 due to plant canopy structure, such as mutual shading, greater affect light interception and light transmission rate.

For below-ground interaction, the sowing proportions has a significant effect on the crop $\mathrm{N}$ and $\mathrm{P}$ uptake, because of the different root growth and distribution of crops in maize-soybean ${ }^{41}$, proso millet-mung bean ${ }^{42}$ intercropping system. The greater lateral root growth, as well as compatibility of spatial root distribution of the component species in intercropping system has a positive effect on crop growth and yield ${ }^{43}$. The $\mathrm{N}$ and $\mathrm{P}$ uptake of wheat in wheat-maize intercropping system improved by approximately $50 \%{ }^{44}$. This sowing proportions in intercrop increases crop root growth and soil volume to capture more water and nutrient in the soil profile ${ }^{41}$. The most important factor contributes to yield under M2S4 intercrop is below-ground competition for P nutrient, as contribution value of crop P uptake, which is consistent with previous studies that yield in intercrop may be more influenced by below- than above-ground crop interaction $s^{27,45}$. Intercropping advantage mainly comes from belowground interaction, including maximized soil nutrients utilization, due to the mingling of the roots of both $\mathrm{crops}^{23}$, water movement and root overlapping activity ${ }^{27}$, greater below-ground space, and a longer life span of crop roots ${ }^{20}$. We found that increased crop P uptake was the main factor leading to the advantages of intercropping, as the contribution rate of crop $\mathrm{P}$ uptake on the biological yield was the highest among below-ground factors, which is consistent with the results observed for cowpea-maize ${ }^{35}$, barley-legume ${ }^{46}$, chickpea-wheat ${ }^{47}$, maize-alfalfa ${ }^{48}$, and common bean-maize ${ }^{49}$ intercropping systems. Increased P uptake in intercrops was mainly 
due to increased root length density ${ }^{41}$, increased $\mathrm{P}$ availability by rhizosphere $\mathrm{pH}$ change ${ }^{35,48}$ or root-induced alkalization $^{49}$, and facilitated organic $\mathrm{P}$ utilization ${ }^{50}$ because the rhizosphere is acidified through the roots $^{51}$.

\section{Conclusions}

Land equivalent ratio were 1.18 and 1.19 for 2:2 and 2:4 intercrops, showing that there were intercropping advantage in land-use efficiency for maize intercropped soybean. The interactions between above- and/or below-ground components was surveyed to improve our understanding of the performance of intercropping. The sowing proportions affects above- and below-ground competition in maize-soybean intercropping systems. The yield under 2:2 and 2:4 intercropping system was mainly determined by diffuse non interceptance, and crop phosphorus uptake, respectively. Thus, above-ground competition was a more important contributor to intercrop advantages than below-ground competition under 2:2 intercrop system, and below-ground competition was significantly higher than above-ground competition to intercrop advantages under 2:4 intercrop system.

\section{Methods}

Site description. Field experiments were conducted at the Changwu Experimental Station $\left(35^{\circ} 12^{\prime} \mathrm{N}, 107^{\circ}\right.$ $40^{\prime}$ E, altitude $1200 \mathrm{~m}$ ) located in Shaanxi Province, China. The experimental site was in the typical dryland farming area on the Loess Plateau. Annual precipitation in the area averaged $582 \mathrm{~mm}$ between 1957 and 2013, with a mean annual temperature of $9.7^{\circ} \mathrm{C}$ over that period. Rainfall and temperature during the two study years are shown in Fig. S1. Soils were generally of the Calcaric Regosol group, according to the FAO/UNESCO soil classification system ${ }^{52}$, and were composed of $4 \%$ sand, $59 \%$ silt, and $37 \%$ clay $^{53}$. The $0-20 \mathrm{~cm}$ soil properties were the following: $\mathrm{pH}, 8.4$; organic matter content, $11.8 \mathrm{~g} \mathrm{~kg}^{-1}$; total $\mathrm{N}$ content, $0.87 \mathrm{~g} \mathrm{~kg}^{-1}$; and Olsen-P, $14.4 \mathrm{mg} \mathrm{kg}^{-1}$.

Experimental design and field management. Two-year experiment was arranged in a randomized complete block design with three replicate plots during 2012 and 2013 growing seasons ${ }^{25,54}$ ENREF_53. The study was conducted using the soybean cultivar (Glycine max L.) cv. Zhonghuang 24 and the maize cultivar (Zea mays L.) cv. Zhengdan 958 grown in cereal-legume agricultural systems. Zhonghuang 24 was bred from Jilin 21 and fendou $31 \times$ Zhongdou 19 (deposition number 2008003); Zhengdan 958 was the offspring of inbred Zheng 58 and Chang 7-2 (deposition number 20000009), which are approved in China. The cropping system treatments were as follows:

1. Sole-cropped soybean $(\mathrm{S})$.

2. Sole-cropped maize $(\mathrm{M})$.

3. Two rows of maize intercropped with two rows of soybean (M2S2).

4. Two rows of maize intercropped with four rows of soybean (M2S4).

Each plot measured $6 \mathrm{~m} \times 4 \mathrm{~m}$, with row spacing of $50 \mathrm{~cm}$ for maize and soybean both in sole crops and intercrops. Individual plants were spaced at $22 \mathrm{~cm}$ and $19 \mathrm{~cm}$ for maize and soybean, respectively, with one plant per stand for maize and two plants per stand for soybean to attain densities of 90,000 and 210,000 plants ha ${ }^{-1}$, respectively. In 2012, seeds of maize and soybean were sown on 25 April and harvested on 28 September, and in 2013, seeds were sown on 20 April and harvested on 25 September. Before sowing, basal fertilizer was applied at a rate of $90 \mathrm{~kg} \mathrm{~N} \mathrm{ha}^{-1}$ as urea $(46 \% \mathrm{~N})$ and $150 \mathrm{~kg} \mathrm{P}_{2} \mathrm{O}_{5}$ ha $^{-1}$ as superphosphate $\left(12 \%, \mathrm{P}_{2} \mathrm{O}_{5}\right)$, and then additional fertilizers were uniformly spread in each plot, which were then ploughed into the $0-30 \mathrm{~cm}$ soil layer using a rotary tiller. All of the plots received $67.5 \mathrm{~kg} \mathrm{~N} \mathrm{ha}^{-1}$ as urea at the bell and silking stages using a hole-seeding machine. No irrigation was applied, and weeds were removed by hand when sighted. The research on plants complied with relevant institutional, national, and international guidelines and legislation.

Above- and below-ground measurements. The Pn was measured with a LI-6400 portable photosynthesis system (LI-COR Inc., Lincoln, NE, USA) from 9:00 to 11:00 h at 120 days after sowing, which corresponds to the milk stage in maize and full seed stage in soybean ${ }^{7,13}$. We measured photosynthesis of ear leaves of maize, the first spreading leaves at the top of soybean in both the sole crops and intercrops. The Pn values were calculated as the sum of the mean readings for five leaves in each plot. The LAI values, DIFN were recorded using a Plant Canopy Analyzer (Li-2200, LiCor Inc., Lincoln, NE, USA) without direct sunlight at milk stage of maize. One above-canopy measurement and three below-canopy measurements at the soil surface were taken for four replicates in each plot. SPAD were collected using a hand-held dual wavelength meter (SPAD 502, Chlorophyll meter, Minolta Camera Co., Ltd., Japan) at milk stage of maize. Measurements were taken midway along the ear leaves of maize and the first spreading leaves at the top of soybean from five adjacent plants at the center of row in each plot.

The SWS was measured gravimetrically using a soil auger at $10 \mathrm{~cm}$ intervals over a depth of $100 \mathrm{~cm}$ and at $20 \mathrm{~cm}$ intervals over a depth of $200 \mathrm{~cm}$ at milk stage of maize for three replicates in each plot. The SWS was calculated for each plot in the $0-200 \mathrm{~cm}$ soil profile for the soil moisture using the following formula: $\mathrm{SWS}=\mathrm{SWC} \times \mathrm{SD} \times \mathrm{SBD}$, where SWC represents soil water content, SD represents soil depth, and SBD represents soil bulk density. Apparent water use during crop growth season was expressed as evapotranspiration (ET), which was determined according to the following formula: ET $=\Delta \mathrm{SWS}+\mathrm{P}$, where $\Delta \mathrm{SWS}$ is the change in soil water storage in the top $200 \mathrm{~cm}$ and $\mathrm{P}$ is the rainfall $(\mathrm{mm})$ between planting and at milk stage in maize. The six adjacent plant samples were collected at milk stage of maize in the middle two rows of each plots (Fig. S2). The sampling included shoots and roots of maize and soybean. At the cotyledonary node, above-ground parts were 
separated from below-ground parts. Soil core samples $(9 \mathrm{~cm}$ diameter $\times 15 \mathrm{~cm})$ at the intra-row of crop were collected to a depth of $100 \mathrm{~cm}$ using an auger and separated in $10-\mathrm{cm}$ sections to determine the root growth in sole-cropping and intercropping systems. The samples were exposed to $105^{\circ} \mathrm{C}$ for $30 \mathrm{~min}$ and then dried to a constant weight at $75^{\circ} \mathrm{C}$. The oven-dried samples were put in small plastic bags after grinding. The study of $\mathrm{N}$ and $\mathrm{P}$ uptake are the most common among mineral elements ${ }^{55,56}$. Concentrations of $\mathrm{N}$ and $\mathrm{P}$ in the plant dry matter were determined after digestion with $\mathrm{H}_{2} \mathrm{SO}_{4}$ and $\mathrm{H}_{2} \mathrm{O}_{2} ; \mathrm{N}$ concentration was measured according to the Kjeldahl method ${ }^{20}$, whereas $\mathrm{P}$ concentration was measured by the molybdenum-antimony anti-spectrophotometric method ${ }^{16}$. Crop $\mathrm{N}$ and $\mathrm{P}$ uptake were calculated by the actual above-ground biomass multiplied by plant tissue $\mathrm{N}$ and $\mathrm{P}$ concentrations. Grain yield was estimated at harvest from $6 \mathrm{~m}^{2}$ for maize and soybean based on the average of three plot replicates.

Data analysis. The LER for assessment of land use advantage. LER is sum of ratio of intercrop to sole crop for maize and soybean yield ${ }^{57}$ :

$$
L E R=L E R_{m}+L E R_{s}, L E R_{m}=\frac{Y_{i m}}{Y_{s m}}, L E R_{s}=\frac{Y_{i s}}{Y_{s s}}
$$

where $L E R_{m}$ and $L E R_{s}$ are patial $L E R$ for maize and soybean, respectively. $Y_{i m}$ and $Y_{i s}$ are yields of maize and soybean under intercrops, respectively. $Y_{s m}$ and $Y_{s s}$ are the yield of maize and soybean under sole crop, respectively.

The water equivalent ratio (WER) was calculated to measure water use advantage of intercropping ${ }^{58}$ :

$$
W E R=W E R_{m}+W E R_{s}, W E R_{m}=\frac{Y_{i m} / E T_{i m}}{Y_{s m} / E T_{s m}}, W E R_{s}=\frac{Y_{i s} / E T_{i s}}{Y_{s s} / E T_{s s}}
$$

where $W E R_{m}$ and $W E R_{s}$ are patial $W E R$ for maize and soybean, respectively. $E T_{i m}$ and $E T_{i s}$ are $E T$ of maize and soybean under intercrops, respectively. $E T_{s m}$ and $E T_{s s}$ are the $E T$ of maize and soybean under sole crop, respectively.

All analyses were conducted in SPSS Statistics 17.0 (SPSS Inc., Chicago, IL, USA). Treatment means showing significant differences among different cropping systems were separated using one-way ANOVA or least significant difference (LSD) at a threshold of 5\% to compare the effect of yield, above- and below-ground related parameters (Pn, LAI, SPAD, DIFN, SWS, N and P uptake) in different maize-soybean intercropping. The variation in Pn, LAI, SPAD, DIFN, SWS, N, and P uptake of crop, and the effects of cropping system $\times$ year were made using Univariate General Linear Models. Pearson's correlation test was used to analyze between LER and above-and below-ground biomass of maize and soybean. The effects of above- and below-ground factors on biological yield were quantified, by calculating the contribution value of some key factors to yield. The effects of between above- (LAI, SPAD, DIFN) and below-ground (SWS, N and P uptake) competition on the biological yield and contribution rate were conducted by the linear regression mode ${ }^{59}$ :

$$
Y=\beta_{0} L A I+\beta_{1} S P A D+\beta_{2} D I F N+\beta_{3} S W S+\beta_{4} \mathrm{~N}+\beta_{5} \mathrm{P}+\beta_{6} X+\beta_{7}
$$

where $Y$ represents biological yield, $L A I$ represents leaf area index, SPAD represents chlorophyll, DIFN represents diffuse non interceptance, $S W S$ represents soil water storage, $N$ represents crop nitrogen uptake, $\mathrm{P}$ represents crop phosphorus uptake, $X$ represents interaction for $L A I, S P A D, D I F N, S W S, N$, and $\mathrm{P}$, and $\beta_{0}, \beta_{1}, \beta_{2}, \beta_{3}, \beta_{4}, \beta_{5}, \beta_{6}$ and $\beta_{7}$ represent the fitted parameters. The standard regression coefficients (Beta) of LAI, SPAD, DIFN, SWS, $\mathrm{N}$, and $\mathrm{P}$ were determined on the basis of Eq. (1) to split their influence on the biological yield by the following equations:

$$
\begin{aligned}
& \beta_{0}^{\prime}=\beta_{0} \times\left(L A I^{\prime} / Y^{\prime}\right) \\
& \beta_{1}^{\prime}=\beta_{1} \times\left(S P A D^{\prime} / Y^{\prime}\right) \\
& \beta_{2}^{\prime}=\beta_{2} \times\left(D I F N^{\prime} / Y^{\prime}\right) \\
& \beta_{3}^{\prime}=\beta_{3} \times\left(S W S^{\prime} / Y^{\prime}\right) \\
& \beta_{4}^{\prime}=\beta_{4} \times\left(\mathrm{N}^{\prime} / Y^{\prime}\right) \\
& \beta_{5}^{\prime}=\beta_{5} \times\left(\mathrm{P}^{\prime} / Y^{\prime}\right)
\end{aligned}
$$

where $\beta_{0}{ }^{\prime}, \beta_{1}{ }^{\prime}, \beta_{2}{ }^{\prime}, \beta_{3}{ }^{\prime}, \beta_{4}{ }^{\prime}$, and $\beta_{5}{ }^{\prime}$ represent the standard regression coefficients for LAI, SPAD, DIFN, SWS, N, and P. $L A I^{\prime}, S P A D^{\prime}, D I F N^{\prime}, S W S^{\prime}, \mathrm{N}^{\prime}$, and $\mathrm{P}^{\prime}$ represent the standard deviations for LAI, SPAD, DIFN, SWS, N, and $P$. $Y^{\prime}$ is the standard deviation for the modeled biological yield.

Received: 1 July 2020; Accepted: 7 July 2021

Published online: 03 August 2021 


\section{References}

1. Raza, M. A., Cui, L., Qin, R., Yang, F. \& Yang, W. Y. Strip-width determines competitive strengths and grain yields of intercrop species in relay intercropping system. Sci. Rep. 10, 1-12. https://doi.org/10.1038/s41598-020-78719-y (2020).

2. Feike, T. et al. How to overcome the slow death of intercropping in China. In: Building sustainable rural futures Proceedings of the 9th European IFSA Symposium 2149-2158 (2010).

3. Vitousek, P. M. et al. Nutrient imbalances in agricultural development. Science 324, 1519-1520. https://doi.org/10.1126/science. 1170261 (2009).

4. Zhang, F., Chen, X. \& Vitousek, P. Chinese agriculture: an experiment for the world. Nature 497, 33-35. https://doi.org/10.1038/ 497033a (2013).

5. Ranells, N. N. \& Wagger, M. G. Grass-legume bicultures as winter annual cover crops. Agron. J. 89, 659-665. https://doi.org/10. 2134/agronj1997.00021962008900040019x (1997).

6. Musa, M. et al. Spatial arrangement affects growth characteristics of barley-pea intercrops. Int. J. Agric. Biol. 12, 685-690. https:// doi.org/10.1111/j.1744-697X.2010.00192.x (2010).

7. Liu, X. et al. Relationships among light distribution, radiation use efficiency and land equivalent ratio in maize-soybean strip intercropping. Field Crop Res. 224, 91-101. https://doi.org/10.1016/j.fcr.2018.05.010 (2018).

8. Pelech, E. A., Drag, D. W., Pederson, T. \& Bernacchi, C. The Microclimate of a Maize-Soybean Intercrop Canopy and Its Influence on Photosynthesis, Light-Interception Efficiency and Water-Use Efficiency (American Geophysical Union, 2018).

9. Murphy, G. \& Dudley, S. Above- and below-ground competition cues elicit independent responses. J. Ecol. 95, 261-272. https:// doi.org/10.1111/j.1365-2745.2007.01217.x (2007).

10. Zhou, T. et al. Improved post-silking light interception increases yield and P-use efficiency of maize in maize/soybean relay strip intercropping. Field Crop Res. 262, 108054. https://doi.org/10.1016/j.fcr.2020.108054 (2021).

11. Zhang, D. et al. Agroforestry enables high efficiency of light capture, photosynthesis and dry matter production in a semi-arid climate. Eur. J. Agron. 94, 1-11. https://doi.org/10.1016/j.eja.2018.01.001 (2018).

12. Li, L., Zhang, L. \& Zhang, F. Crop mixtures and the mechanisms of overyielding. Encycl. Biodivers. 2, 382-395. https://doi.org/10. 1023/A:1022352229863 (2013).

13. Yang, F. et al. Effect of aboveground and belowground interactions on the intercrop yields in maize-soybean relay intercropping systems. Field Crop Res. 203, 16-23. https://doi.org/10.1016/j.fcr.2016.12.007 (2017).

14. Mushagalusa, G. N., Ledent, J. F. \& Draye, X. Shoot and root competition in potato/maize intercropping: Effects on growth and yield. Environ. Exp. Bot. 64, 180-188. https://doi.org/10.1016/j.envexpbot.2008.05.008 (2008).

15. Saberali, S. F. \& Mohammadi, K. The above-ground competition between common bean (Phaseolus vulgaris L.) and barnyardgrass (Echinochloa crus-galli L.) affected by nitrogen application. Phytoparasitica 47, 1-10. https://doi.org/10.1007/s12600-019-00745-y (2019).

16. Lv, Y., Francisef, C., Wu, P., Chen, X. \& Zhao, X. Maize-soybean intercropping interactions above and below ground. Crop Sci. 54, 914-922. https://doi.org/10.2135/cropsci2013.06.0403 (2014)

17. Wu, Y. et al. Responses to shade and subsequent recovery of soybean in maize-soybean relay strip intercropping. Plant Prod. Sci. 15, 1-9. https://doi.org/10.1080/1343943X.2015.1128095 (2016).

18. Yin, W. et al. Innovation in alternate mulch with straw and plastic management bolsters yield and water use efficiency in wheatmaize intercropping in arid conditions. Sci. Rep. 9, 1-14. https://doi.org/10.1038/s41598-019-42790-x (2019).

19. Li, L. et al. Root distribution and interactions between intercropped species. Oecologia 147, 280-290. https://doi.org/10.1007/ s00442-005-0256-4 (2006).

20. Li, L., Sun, J. \& Zhang, F. Intercropping with wheat leads to greater root weight density and larger below-ground space of irrigated maize at late growth stages. Soil Sci. Plant Nutr. 57, 61-67. https://doi.org/10.1080/00380768.2010.548307 (2011).

21. Donald, C. M. The interaction of competition for light and for nutrients. Aust. J. Agric. Res. 9, 421-435. https://doi.org/10.1071/ $\operatorname{ar} 9580421(1958)$.

22. Hassan, A., Kodoh, J., Kamu, A., Majius, R. \& Yunus, N. Root interactions on sole crop and intercrop give different effects of competition. IOP Conf. Ser.: Earth Environ. Sci. 449, 1-5. https://doi.org/10.1088/1755-1315/449/1/012012 (2020).

23. Thorsted, M., Weiner, J. \& Olesen, J. Above- and below-ground competition between intercropped winter wheat Triticum aestivum and white clover Trifolium repens. J. Appl. Ecol. 43, 237-245. https://doi.org/10.1111/j.1365-2664.2006.01131.x (2006).

24. Raza, M. A. et al. Optimum leaf defoliation: A new agronomic approach for increasing nutrient uptake and land equivalent ratio of maize soybean relay intercropping system. Field Crop Res. 244, 1-11. https://doi.org/10.1016/j.fcr.2019.107647 (2019).

25. Zou, X. et al. Interspecific root interactions enhance photosynthesis and biomass of intercropped millet and peanut plants. Crop Pasture Sci. 70, 234-243. https://doi.org/10.1071/cp18269 (2019).

26. Semere, T. \& Froud-williams, R. J. The effect of pea cultivar and water stress on root and shoot competition between vegetative plants of maize and pea. J. Appl. Ecol. 38, 137-145. https://doi.org/10.1046/j.1365-2664.2001.00570.x (2010).

27. Chen, G. et al. Belowground interspecies interaction enhances productivity and water use efficiency in maize-pea intercropping systems. Crop Sci. 55, 420-428. https://doi.org/10.2135/cropsci2014.06.0439 (2015).

28. Wang, L. et al. The effects of plastic-film mulch on the grain yield and root biomass of maize vary with cultivar in a cold semiarid environment. Field Crop Res. 216, 89-99. https://doi.org/10.1016/j.fcr.2017.11.010 (2018).

29. Sun, J. et al. Maize canopy photosynthetic efficiency, plant growth, and yield responses to tillage depth. Agronomy 9, 1-18. https:// doi.org/10.3390/agronomy9010003 (2019).

30. Nweke, I. A. \& Anene, O. H. Effect of maize/bambara groundnut intercrop on soil properties, growth and yield parameter of the intercrop species. Eur. J. Agric. For. Res. 7, 16-28 (2019).

31. Moreira, A., Moraes, L. A. C., Schroth, G. \& Mandarino, J. M. G. Effect of nitrogen, row spacing, and plant density on yield, yield components, and plant physiology in soybean-wheat intercropping. Agron. J. 107, 2162-2170. https://doi.org/10.2134/agronj15. 0121 (2015).

32. Liu, X. et al. PAR interception and utilization in different maize and soybean intercropping patterns. PLoS ONE 12, 1-17. https:// doi.org/10.1371/journal.pone.0169218 (2017).

33. Dutra, W. F. et al. Photosynthetic efficiency, gas exchange and yield of castor bean intercropped with peanut in semiarid Brazil. Revista Brasileira de Engenharia Agrícola e Ambiental 21, 106-110. https://doi.org/10.1590/1807-1929/agriambi.v21n2p106-110 (2017).

34. Feng, G. et al. Relationship between plant canopy characteristics and photosynthetic productivity in diverse cultivars of cotton (Gossypium hirsutum L.). Crop J. https://doi.org/10.1016/j.cj.2016.05.012 (2016).

35. Latati, M. et al. The intercropping cowpea-maize improves soil phosphorus availability and maize yields in an alkaline soil. Plant Soil 385, 1-11. https://doi.org/10.1007/s11104-014-2214-6 (2014).

36. Kanwar, R. S. et al. Corn-soybean and alternative cropping systems effects on $\mathrm{NO}^{3}-\mathrm{N}$ leaching losses in subsurface drainage water. Appl. Eng. Agric. 21, 181-188. https://doi.org/10.13031/2013.18151 (2005).

37. Liu, T. D. \& Song, F. B. Maize photosynthesis and microclimate within the canopies at grain-filling stage in response to narrowwide row planting patterns. Photosynthetica 50, 215-222. https://doi.org/10.1007/s11099-012-0011-0 (2012).

38. Yang, F. et al. Growth of soybean seedlings in relay strip intercropping systems in relation to light quantity and red far-red ratio. Field Crops Res. 155, 245-253. https://doi.org/10.1016/j.fcr.2013.08.011 (2014). 
39. Awal, M. A., Koshi, H. \& Ikeda, T. Radiation interception and use by maize/peanut intercrop canopy. Agric. For. Meteorol. 139, 74-83. https://doi.org/10.1016/j.agrformet.2006.06.001 (2006).

40. Gou, F. et al. Intercropping wheat and maize increases total radiation interception and wheat RUE but lowers maize RUE. Eur. J. Agron. 84, 125-139. https://doi.org/10.1016/j.eja.2016.10.014 (2017).

41. Ren, Y., Wang, X., Zhang, S., Palta, J. \& Chen, Y. Influence of spatial arrangement in maize-soybean intercropping on root growth and water use efficiency. Plant Soil 415, 131-144. https://doi.org/10.1007/s11104-016-3143-3 (2017).

42. Gong, X. et al. Interspecific root interactions and water-use efficiency of intercropped proso millet and mung bean. Eur. J. Agron. 115, 126034. https://doi.org/10.1016/j.eja.2020.126034 (2020).

43. Gao, Y. et al. Distribution of roots and root length density in a maize/soybean strip intercropping system. Agric. Water Manag. 98, 199-212. https://doi.org/10.1016/j.agwat.2010.08.021 (2010).

44. Zhang, F. \& Li, L. Using competitive and facilitative interactions in intercropping systems enhances crop productivity and nutrientuse efficiency. Plant Soil 248, 305-312. https://doi.org/10.1023/A:1022352229863 (2003).

45. Wu, K. et al. Above- and below-ground interspecific interaction in intercropped maize and potato: A field study using the 'target' technique. Field Crops Res. 139, 63-70. https://doi.org/10.1016/j.fcr.2012.10.002 (2012).

46. Darch, T. et al. Inter- and intra-species intercropping of barley cultivars and legume species, as affected by soil phosphorus availability. Plant Soil 427, 125-138. https://doi.org/10.1007/s11104-017-3365-z (2018).

47. Betencourt, E., Duputel, M., Colomb, B., Desclaux, D. \& Hinsinger, P. Intercropping promotes the ability of durum wheat and chickpea to increase rhizosphere phosphorus availability in a low P soil. Soil Biol. Biochem. 46, 181-190. https://doi.org/10.1016/j. soilbio.2011.11.015 (2012).

48. Sun, B. et al. The relative contributions of $\mathrm{pH}$, organic anions, and phosphatase to rhizosphere soil phosphorus mobilization and crop phosphorus uptake in maize/alfalfa polyculture. Plant Soil https://doi.org/10.1007/s11104-019-04110-0 (2019).

49. Latati, M. et al. The intercropping common bean with maize improves the rhizobial efficiency, resource use and grain yield under low phosphorus availability. Eur. J. Agron. 72, 80-90. https://doi.org/10.1007/s11104-014-2214-6 (2016).

50. Li, L., Tang, C., Rengel, Z. \& Zhang, F. Chickpea facilitates phosphorus uptake by intercropped wheat from an organic phosphorus source. Plant Soil 248, 297-303. https://doi.org/10.1023/a:1022389707051 (2003).

51. Li, L., Li, S., Zhou, L. \& Zhang, H. Diversity enhances agricultural productivity via rhizosphere phosphorus facilitation on phosphorus-deficient soils. Proc. Natl. Acad. Sci. 104, 11192-11196. https://doi.org/10.1073/pnas.0704591104 (2007).

52. Wang, J., Liu, W. Z., Mu, H. F. \& Dang, T. H. Inorganic phosphorus fractions and phosphorus availability in a calcareous soil receiving 21-year superphosphate application. Pedosphere 20, 304-310. https://doi.org/10.1016/s1002-0160(10)60018-5 (2010).

53. Gong, Z., Zhang, G. \& Chen, Z. Pedogenesis and Soil Taxonomy (Beijing Science Press Publish, 2007).

54. Zheng, C. et al. Effects of mulch and irrigation regimes on water distribution and root competition in an apple-soybean intercropping system in Loess Plateau, China. Agric. Water Manag. 246, 106656. https://doi.org/10.1016/j.agwat.2020.106656 (2021).

55. Cowden, R. et al. Nitrogen fertilizer effects on pea-barley intercrop productivity compared to sole crops in Denmark. Sustainability 12, 1-17. https://doi.org/10.3390/su12229335 (2020).

56. Wang, L., Zhou, T., Cheng, B., Du, Y. \& Yang, W. Variable light condition improves root distribution shallowness and p uptake of soybean in maize/soybean relay strip intercropping system. Plants 9, 1-21. https://doi.org/10.3390/plants9091204 (2020).

57. Rao, M. R. \& Willey, R. W. Evaluation of yield stability in intercropping: Studies on sorghum/pigeonpea. Exp. Agric. 16, 105-116. https://doi.org/10.1017/S0014479700010796 (1980).

58. Mao, L. et al. Yield advantage and water saving in maize/pea intercrop. Field Crop Res. 138, 11-20. https://doi.org/10.1016/j.fcr. 2012.09.019 (2012).

59. Zhang, Y. et al. Litter production rates and soil moisture influences interannual variability in litter respiration in the semi-arid Loess Plateau, China. J. Arid Environ. 125, 43-51. https://doi.org/10.1016/j.jaridenv.2015.09.016 (2016).

\section{Acknowledgements}

This work was financially supported by National Natural Science Foundation of China $(41901025,41801069)$, Open Foundation of State Key Laboratory of Soil Erosion and Dryland Farming on the Loess Plateau (A314021402-1712), Shaanxi National Science Foundation (2019JQ-895), Youth Talent Promotion Project of Shaanxi Association for Science and Technology (20200705), and PhD research startup foundation of Baoji University of Arts and Sciences (ZK2017042).

\section{Author contributions}

S.Q.Z. initiated and designed the research. Y.Y.R., M.F.Y. performed the experiments. Y.Y.R., Y.J.Z and L.Z. analyzed the data. Y.Y.R wrote the paper. Y.L.C., J.A.P., S.Q.Z. revised and edited the manuscript. All authors approved the final manuscript.

\section{Competing interests}

The authors declare no competing interests.

\section{Additional information}

Supplementary Information The online version contains supplementary material available at https://doi.org/ 10.1038/s41598-021-95242-w.

Correspondence and requests for materials should be addressed to S.Z.

Reprints and permissions information is available at www.nature.com/reprints.

Publisher's note Springer Nature remains neutral with regard to jurisdictional claims in published maps and institutional affiliations. 
(c) (i) Open Access This article is licensed under a Creative Commons Attribution 4.0 International cc) License, which permits use, sharing, adaptation, distribution and reproduction in any medium or format, as long as you give appropriate credit to the original author(s) and the source, provide a link to the Creative Commons licence, and indicate if changes were made. The images or other third party material in this article are included in the article's Creative Commons licence, unless indicated otherwise in a credit line to the material. If material is not included in the article's Creative Commons licence and your intended use is not permitted by statutory regulation or exceeds the permitted use, you will need to obtain permission directly from the copyright holder. To view a copy of this licence, visit http://creativecommons.org/licenses/by/4.0/.

(C) The Author(s) 2021 